\title{
BEYOND THE FRONT-LINE: THE COPING STRATEGIES AND DISCRETION OF LITHUANIAN STREET-LEVEL BUREAUCRACY DURING COVID-19
}

\author{
REMIGIJUS CIVINSKAS - JAROSLAV DVORAK - GINTARAS ŠUMSKAS ${ }^{l}$
}

\begin{abstract}
This article presents the results of a project funded by the Research Council of Lithuania: 'Public policy solutions and their improvement to overcome the COVID-19 crisis in Lithuanian municipalities: solution tools and service delivery.' The research methodology is based on street-level bureaucracy theory and ongoing qualitative research in the form of interviews with social workers and doctors. Interviews were conducted in the Lithuanian municipalities which became the first COVID-19 hotspots in March-April 2020. The aim is to identify the response and coping strategies of street-level bureaucracy. The findings of current research suggest that the workload of street-level bureaucrats increased, the situation changed very rapidly, and there was a constant need to adopt rules and even recommendations issued by the ministry. Fear of COVID-19 infection, a lack of accurate information, uncertainty, and the possibility of allowing staff with children to leave the workplace led to staff shortages. This in turn motivated the administration and the remaining employees to look for suitable coping strategies.
\end{abstract}

KEYWORDS: COVID-19, street-level bureaucracy, crisis response, social workers, Lithuania

\footnotetext{
1 Remigijus Civinskas works at Vytautas Magnus University, Lithuania; email: remigijus.civinskas@, vdu.lt; Jaroslav Dvorak works at Klaipeda University, Lithuania; email: jaroslav.dvorak@ku.lt; Gintaras Šumskas works at Vytautas Magnus University, Lithuania: email: Gintaras.sumskas@vdu.lt This project received funding from the Research Council of Lithuania (LMTLT), agreement No. P-COV-20-59.
} 


\section{INTRODUCTION}

The COVID-19 pandemic forced governments at all levels to seek solutions by developing specific crisis-response policies, which were shaped by the adaptation of public health or other crisis management models or the development of new, completely specific response tools (Weible et al. 2020). Research shows that the COVID-19 pandemic as a crisis is unique and distinctive in most respects (Hsiang et al. 2020; van Bavel et al. 2020). The complex public policy challenges posed by the COVID-19 crisis elicited a response from governments and subnational actors. These policies began with an initial response and later shifted to the mitigation of constraints and consequences (Hale et al. 2020). These heterogeneous responses and crisis-response policies differ somewhat in their design, objectives, formulation, and implementation processes. The question is to what extent the success of anti-crisis policies (effective feasibility) depends on their formation (the formulation of appropriate goals, and the choice of coordination model), and to what extent this can determine the implementation thereof. It is understandable that government-led crisis-response policies (the so-called top-down model) are critical.

On the other hand, research shows that responsive policies are highly unstable, as well as often poorly coordinated (Hale et al. 2020; Turrini et al. 2020). One of the unknowns concerns uncertainty with regard to the conclusions of public policy decisions. Policy implementation is also critical, especially the involvement of epidemiologists / public-health professionals, doctors, social service providers and other staff working on the frontlines of the battle with the COVID-19 virus.

The implementation of COVID-19 crisis management policies in the field of personal health and health services was selected for the empirical study. The areas of social and personal health services were chosen for several reasons: (1) they were important in the context of crisis management during the coronavirus pandemic and were addressed by COVID-19 crisis management policy; (2) in terms of the implementation of policies, a significant part of the responsibilities (prevention of the spread of infection, management of the epidemiological situation, etc.) fell on the municipalities; (3) in the context of COVID-19 crisis policy, the functioning of some officials (mainly front-line staff) with wide discretion was crucial. Physicians and social workers were able to compensate for inadequate crisis management solutions and failed measures.

The current research aims to investigate the effectiveness of the implementation of COVID-19 crisis management policies in Lithuania for social and personal health services. Based on the theoretical approach of street-level bureaucracy, the aim is to determine the coping strategies and changes in the discretion 
of street-level bureaucrats (i.e. how did changing public policy decisions [emergency decisions] change the discretion of the street-level bureaucracy?). The key question is what coping mechanisms and strategies for overcoming the problems caused by COVID-19 have been developed by doctors and social workers working directly with patients and clients. The results of the study should explain the gaps in health and social services systems and help to improve existing emergency management systems. The research will also be significant in terms of the application and development of the theory, and help explain how the theory of street-level bureaucracy can be adapted to the study of crisis management policies.

\section{THE COVID-19 PANDEMIC AND THE THEORY OF STREET-LEVEL BUREAUCRACY}

The work of street-level officials (doctors and social service providers) in providing services to clients was important in the implementation of the policies that responded to the crisis caused by COVID-19 (especially in providing services to the population). The analytical perspective of the study will be presented in this section in order to systematically analyze employee behavior (coping strategies) and determinants (situational conditions of service provision, the effects of the identities of close employees, and the importance of discretion).

\section{Working conditions of street-level bureaucracy}

Lipsky (2010), the pioneer of the theory of street-level bureaucracy, in defining the concept of a street-level servant ("street-level bureaucrat"), noticed that the latter are employees who are in direct contact with customers and undertake their work - the provision of public services - under severe constraints (structural constraints). These disadvantages are primarily due to limited resources. Many resources (time, material, financial, knowledge, etc.) that are required to ensure the proper provision of services are lacking (see Figure 1). This lack of resources is usually due to practical constraints arising from requirements related to the large number of patients, the requirement of filling in forms in electronic systems/registers, etc. (Lipsky 2010). Street-level staff often lack resources due to structural factors such as the underfunding of services or the unequal distribution of budgets. On the other hand, the growing demand for services may also lead to a lack of resources, which hinders the provision of 
services that meet customer expectations. Consequently, street-level servants face dilemmas on a daily basis - involving a lack of resources and increasing demand for services. The emergence of such a dilemma has been underlined by many theorists who seek to develop the theory of street-level bureaucracy (Brodkin 2020; Maynard-Moody-Musheno 2003), and the phenomenon has been confirmed and revealed in detail by numerous empirical studies (Small 2006; Spitzmueller 2014; Trappenburg et al. 2020).

Street-level employees are faced with large workloads (a large number of customer services, the additional workload related to documentation management, information systems, and other similar activities). This is another factor (in addition to the lack of resources and the desire to respond to the individual needs and expectations of the client) which causes tension (Lipsky 2010; Dvorak-Savickaite 2018). It is important to note that heavy workloads can begin to emerge not only during seasonal peaks, but also during unexpected crises. Street-level servants look for solutions to such problematic situations by trying to redistribute workloads or choose other coping strategies (MaynardMoody-Musheno 2003; Hupe-Buffat 2014). The biggest problems which they face are caused by two factors that often go together - a large workload and a lack of resources. This combination is difficult to endure when working on the front lines on a daily basis. Major crises exacerbate negative effects and can be very difficult to overcome. These factors are not the only ones that complicate work. In difficult situations, street-level officers are also affected by the uncertainty associated with the contradiction of implementing policies that are "dropped" on them from above (see Figure 1).

\section{Uncertainty in the implementation of public policies}

Street-level bureaucrats face uncertainty when making decisions. This arises from the heterogeneity, ambiguity, contradiction, etc. of the public policies that are implemented (on the basis of which they participate in the process of providing services to customers). More specifically, feelings of uncertainty (and thus doubts about the provision of solutions and services) often arise for streetlevel bureaucrats due to the contradiction or incompleteness of policy objectives. Regulatory procedures created by public policies are also unclear (RaaphorstGroeneveld 2019). Feelings of uncertainty about policy implementation affect employees in the context of their day-to-day decisions. On the one hand, the latter have some freedom of choice and can choose how to act. On the other hand, they work with clients, which poses some challenges (Raaphorst 2018). However, in the case of major crises, managerial referrals may be acceptable 
to them. Raaphorst (2018) systematizes research on feelings of uncertainty for close employees and their impact on decision-making.

The uncertainty factor is often intertwined with the attitudes and emotions of close employees, possibly even leading to physical fatigue. Researcher Van Engen and her co-authors examined how so-called reception staff (those working on the front lines) evaluate (accept, justify, understand as significant, and react to the activities related to the implementation of) national public policies (Van Engen et al. 2019). The results of this study show that policy integrity and continuity are important for reception staff, even if public policies need to change.

\section{The discretion (power of self-determination) of street-level employees and the changes during the crisis}

Autonomy in the provision of services is important for the functioning of street-level employees (see Figure 1). Decision autonomy allows employees to work according to their ideals, professional competencies, and ethical norms (Lipsky 2010). Indeed, the conceptualization of the phenomenon of the discretion of street-level servants is a central element in the theory of street-level bureaucracy.

The conceptualization of the study of the discretion of street-level servants involves two fundamental difficulties. The concept of discretion has changed in the theory of street-level bureaucracy. Lipsky (2010), refining his theory, noted that discretion and contact with citizens are important concepts that distinguish status. In the theoretical scientific approach in question, the concept of discretion is defined and used slightly differently depending on certain contexts. Specifically, researchers have not developed a coherent concept of discretion (Tummers-Bekkers 2014; Hupe 2013; Pivoras-Gončiarova 2017).

Lipsky (2010) sees the discretion of a street-level servant as a gift - a degree of decision autonomy is given to the servant by the ruler (usually "top-down"). In this case, it is understood as a prescriptive right (understood through the development of differences - public policy "as written" and "public policy as an activity"). According to another, revised approach, discretion is defined as the actual autonomy of a staff member's decisions or conduct which may be exercised in a particular environment (Tummers-Bekkers 2014; Buffat 2016). Maynard-Moody and Musheno (2003) rightly observe that discretion "is defined in many pieces of legislation as a certain legal heritage." Consequently, a public official must create landmarks within his or her frame and "travel through them" according to the many possible limitations. 
Figure 1. The effects of the COVID-19 crisis on the behavior of street-level officials

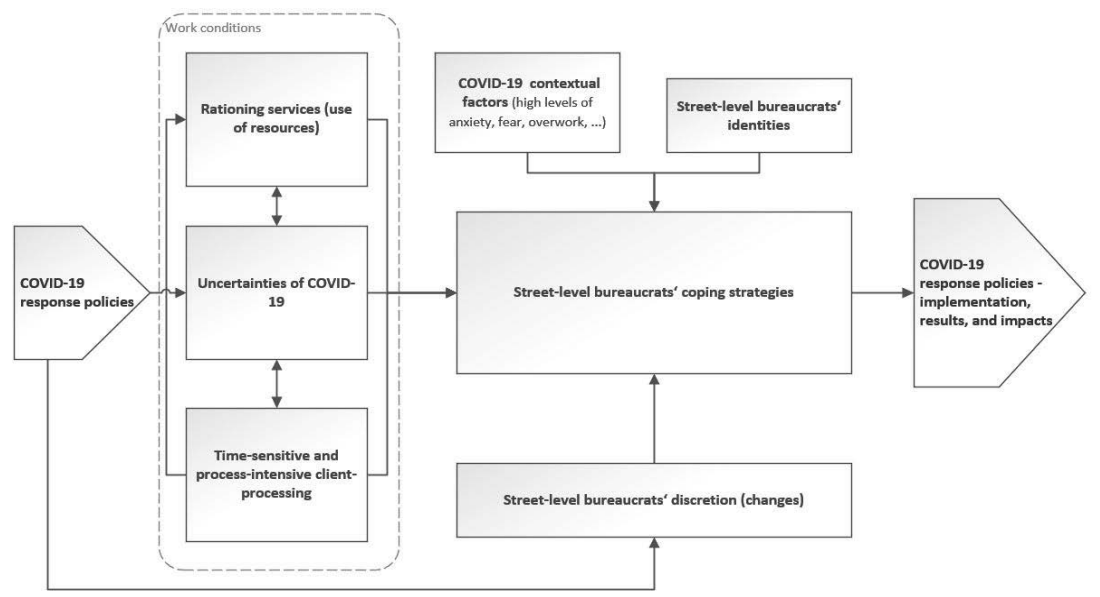

Source: Authors' construction

Discretion is divided into two forms: legal / de jure ("as described"), and factual ("as it is"). Obviously, this difference needs to be taken into account. On one hand, when analyzing the performance of street-level employees, the actual autonomy of their decisions in providing services to customers is more important for many reasons. However, it is vital to note that the effectiveness of the services provided and the implementation of public policy may depend on discretion. This aspect of outcome and impact is crucial (Hupe 2013). For example, with de facto discretion, street-level employees can focus on meeting customer needs, showing more empathy, devoting more resources to them, and so on. On the other hand, such discretion can lead to malfunctioning (or inaction) and even abuse. Thus, the choices of a street-level servant depend on how they understand and interpret the rules.

The discretion of a street-level employee depends on the individual position (whether one is, e.g., a doctor, nurse, or social worker), service institutions (one form of discretion will apply to a social worker working in a social care home with the elderly, and another in a hostel for the homeless). More specifically, employee discretion may depend on the legal regime of the service, the institution's internal rules, and so on. In some studies, groups of close employees are distinguished according to the level of decision autonomy available to them: administrative (Sowa-Selden 2003), narrow (Pivoras-Gončiarova 2017), or reception discretion (Ellis 2014; Scourfield 2015). 
The concept of the discretion of street-level employees in the public policy literature is related to the differentiation of implementation methods. Under traditional policy implementation schemes, two interpretations of streetlevel bureaucratic discretion are possible: (1) a top-down, and (2) a bottomup formation (which can be called actual discretion). According to the latter interpretation, discretion is understood as a condition that helps employees to effectively implement public programs or provide services (i.e. they can properly allocate limited resources and prioritize complex tasks) (Maynard-MoodyMushano 2003; Watkins-Hayes 2009). In addition, empirical research has shown that the discretion of street-level employees (bottom-up implementation) shapes and strengthens the employee's orientation towards the client (understanding the significance of the client, and aspiring to help them) (Tummers-Bekkers 2014).

Studies of street-level bureaucracy have shown that the discretion of public sector employees is changing due to one noticeable trend-modern management systems (quality, performance, human resource management, etc.) along with individual measures (service standards, decision and monitoring systems, performance evaluation, etc.) (Evans-Harris 2004; Ponnert-Svensson 2016; Brodkin 2007; Hupe 2007). On the other hand, a number of public services and authorities are contracted out from the private sector, using mixed (socalled public-private partnership) organizational models. It is important to take this into account when public services are introduced during crises (such as epidemics) (on the basis of the imperative or voluntary involvement of the authorities) and private institutions (clinics, doctors' offices, social service companies, etc.).

\section{Strategies for coping with the problems of street-level employees}

As already discussed, the activities of street-level employees are influenced by different and simultaneously existing factors - difficult working conditions (a constant lack of resources, uncertainty about 'drop-down' policies, a large number of tasks), changing discretion, and varying identities. These factors determine the behavior of employees (based on certain conditions or decision guidelines) who are in direct contact with customers during the provision of services. However, problem-solving behavior is a key concept that explains the gaps in the implementation of public policy and best reveals the difficulties that employees may face. There is a consensus in research that coping techniques (sometimes expanded to include forms, strategies, and styles) are the basis for helping individuals to meet the challenges they face (Dubois 2016; Tummers et al. 2015). 
The concept of coping behaviors was first introduced by Lipsky in developing the theory of street-level bureaucracy. According to Lipsky:

[...] I sought to find out the coping behaviors of street-level servants. In analyzing this, I highlighted the gap between the idea of ideal services and practical situations. [...] In addition, coping behaviors of street-level officials increase the differences in public policy in the implementation process between how it is written and how it is actually implemented. Other coping strategies reflect trade-offs between the policy formulated and the needs of a street-level bureaucracy. (Lipsky 1980)

This quote reveals that street-level employees use problem-coping techniques (mechanisms and strategies) to realize their ideals in their daily activities. To achieve their ideals, they have to overcome two common obstacles: a lack of resources, and operational constraints due to limited discretion. According to previous research, it is no simple task to do this successfully.

Coping with the problems of service providers is one of the key concepts in Lipsky's theory (together with the concepts of formalist service, and people processing) (Lipsky 2020). As previously mentioned, this explains the gaps in the policy implementation process, while revealing how officials reduce the latter through their behavior. On the other hand, Lipsky (2020) did not clearly reveal this concept and did not conceptualize the types of coping mechanisms and their application. In other words, the creator of street-level bureaucracy did not provide explanatory (so-called operational) concepts. Its interpretations do not reflect the realities of the operation of today's street-level bureaucracy in relation to the application of public management and market measures in the public sector.

The concept of coping with problems was further developed by many of Lipsky's followers. The most striking of these are the contributions of Tummers and his colleagues. These scholars singled out and described the coping strategies, mechanisms, and styles used by street-level employees (Tummers et al. 2015). They also explained the factors (linked to those already singled out in the theory of street-level bureaucracy and supplemented by psychological interpretations) that determine the emergence of one strategy or another, the changes thereto and the impact of their application on public policies. Consequently, this group of scientists (who have collaborated on many publications) developed a unique method for the development of the theory of street-level bureaucracy that has three striking directions: (1) clarifications of the definition of the concept of coping; (2) a presentation of classifications of coping mechanisms (types); and 
(3) analysis of the factors influencing (positive or negative) coping and the impact thereof.

\section{The impact of COVID-19 on street-level bureaucracy}

The performance of public sector employees during times of crisis has seldom been addressed through the theoretical approach of street-level bureaucracy. For example, several publications examined the activities of social service providers during the refugee crisis in 2015-2017 (Sicgling 2020; Fontana 2019; Giudici, 2020; Borrelli-Lindberg 2018). Henderson (2012) discussed the roles of street-level servants during natural cataclysms and crises. He noted that such roles are critically significant. However, the main researchers of streetlevel bureaucracy paid relatively little attention to the topic of crises. This is likely to be due to the short duration of these crises and the unsuitability of the topic for research. Some front-line workers often work in conditions that are similar to some crises. Thus, the question why delve into short-term crises individually arises.

First, the potential approaches to research in the framework of public policy research, and more narrowly in terms of the study of street-level bureaucracy, have been discussed by two groups of theorists. Dunlop et al. (2020) highlighted the study of street-level bureaucrats as one of the most appropriate top-down approaches to implementing public policies. A team of Brazilian scientists led by Alcadipani et al. (2020) analyzed the work of police officers as street-level bureaucrats during the COVID-19 pandemic. The team of researchers arrived at several important conclusions based on the data they obtained. The researchers noted that the behavior of policemen was determined by both identification with the needs of society and other factors, such as conflicting public policy decisions (between presidential, federal, and state-level institutions), elements of professional culture, and a lack of resources.

In our view, it is important to continue the study of changes in discretion, assuming that the autonomy of service providers decreases during a crisis. It should be noted that the conceptualization of the phenomenon of discretion in street-level bureaucracy is a central element in the theory of street-level bureaucracy. Lipsky (2010), similarly to most of his followers, saw the discretion of a street-level bureaucrat as freedom to make decisions within the scope of the policy-making process, as encouraged by certain incentives and limited by sanctions. The decisions of a doctor or a social worker can be determined by contextual factors pertaining to normative and public policy, a lack of resources, or the complexity of assigned tasks (or policy goals). 
During the COVID-19 crisis, the uncertainty of decisions increased several times for street-level bureaucrats. This was due not only to the effects of the crisis and changing discretion, but also to atypical interactions with clients. Street-level bureaucrats encounter heavy workloads, conflicting requirements (as set out in public policy documents), a lack of resources, and other difficulties when working with clients (Lipsky 2010; Tummers et al. 2015). This eventually puts them under stress during the provision of services and leads to emotional 'burnout' situations. In applying the theory of street-level bureaucracy, the effects of a lack of resources and emotional effects (the anxiety of street-level bureaucrats about personal and family security) were also examined. In this way, the theoretical model under consideration was extended.

\section{THE COVID-19 RESPONSE IN LITHUANIA}

A state of emergency in Lithuania was declared on February 26, 2020. With this decision, the government sought to facilitate the coordination of preventive action, prepare for the spread of COVID-19 in the country, organize the work of the responsible institutions, and use the state reserves of medical resources to implement procedures faster and easier. On February 27, 2020, the Minister of Health was appointed head of the operation and took over the command of the National Emergency Situations Center. Despite the fact that the state was said to be ready to meet the challenge of the COVID-19 pandemic, it soon became clear that the most basic protective measures (masks, disinfectant, protective equipment for doctors) were lacking (Dvorak 2020). The testing of the population began to flounder because the aim was to implement testing by sending the tests centrally to the capital city, Vilnius.

As the scale of the pandemic accelerated, the number of infected medical staff began to grow. According to data from April 7, 2020, 154 health care professionals in Lithuania became ill. Due to the strict lockdown, the activities of many business organizations and public sector institutions (e.g. schools and universities) were limited, though not including grocery stores, gas stations, and pharmacies. The borders were closed, except for shipments of protective equipment through Vilnius Airport and the return of Lithuanian residents by ferry through Klaipeda State Seaport. Thanks to these measures, the situation was managed from a short-term perspective. Indeed, on May 15, 2020, the freedom of movement of the population was restored, leading the global media to refer to the area as the Baltic Bubble (Dvorak 2021). 
At the same time, the Lithuanian government approved a COVID-19 management strategy, which was designed to be implemented within two years and could be reviewed if a vaccine and / or drug were to be developed. Although the summer of 2020 seemed to indicate that COVID-19 would be controlled and overcome, morbidity rates began to rise rapidly in early September. Until the present date, it can be stated that they are higher or similar to those of many EU countries.

\section{METHODOLOGY}

Qualitative research involving street-level employees. In analyzing the performance of street-level employees, a qualitative research method was used to select the form of individual and group interviews. Data were collected consistently based on sound methods. Initially, preparatory informal interviews were conducted with social workers and doctors. Later, after the preparation of the study (the selection criteria, research topics and questions, etc.) and the planning of its implementation, the collection of qualitative data began.

It is important to note that the study was conducted in five municipalities. The municipalities with the largest populations - namely, Vilnius, Kaunas, and Klaipeda - and the municipalities of districts with a higher incidence of COVID-19 than average (Marijampole and Ukmergè) were selected (April May 2020). Experiences of street-level bureaucrats with outbreaks of infection (including both those in direct contact with the institutions, and indirectly, those who knew about the situation in the municipality, took preventive steps, and prepared for virus control) were analyzed. According to these criteria, five groups of informants were distinguished (see Table 1).

Table 1. Qualitative research informants, street-level employees

\begin{tabular}{ccccc}
\hline $\begin{array}{c}\text { Employees of } \\
\text { social care homes } \\
\text { and hostels } \\
\text { (social workers, } \\
\text { nurses) }\end{array}$ & $\begin{array}{c}\text { Staff of inpatient } \\
\text { personal health } \\
\text { institutions, } \\
\text { doctors at } \\
\text { infection clinics, } \\
\text { nurses }\end{array}$ & $\begin{array}{c}\text { Social service } \\
\text { providers } \\
\text { (social workers) } \\
\text { providing } \\
\text { services at home }\end{array}$ & $\begin{array}{c}\text { Social service } \\
\text { providers } \\
\text { (social workers) } \\
\text { providing } \\
\text { services at home* }\end{array}$ & $\begin{array}{c}\text { Doctors who } \\
\text { provided } \\
\text { services } \\
\text { remotely* }\end{array}$ \\
\hline 9 & 10 & 7 & 10 & 3 \\
\hline
\end{tabular}

*During the quarantine period, from March 14 to June 16, 2020; after the quarantine period, who worked with clients and had contact with them.

Source: Prepared by authors 
This choice of groups of informants was required to meet several main selection criteria: (1) the latter should be involved in the response to the dissemination of a wide range of services (which were provided rather than terminated during the first quarantine); (2) the attention of employees to the risk of coronavirus should be elevated, or include those with experience working with at-risk groups.

Two forms of interviews were chosen: individual and group interviews. Thirty-two individual and two group interviews were conducted (with social service providers in Marijampole and Klaipeda). A total of 39 interviewees participated in the study. In terms of occupational distribution, most informants were social workers and their assistants (24), with slightly smaller numbers of doctors (14) and nurses (3). The distribution of interviews by municipalities was as follows: Marijampole district municipality (10); Kaunas city (6); Vilnius city (9); Klaipeda city (5); and Ukmergè district (4). The interviews were conducted in September-November 2020.

Individual interviews lasted between half an hour and an hour and a half. About half of the interviews were conducted during face-to-face meetings, mostly at the premises of health and social services. Some informants refused to take part in face-to-face meetings due to the deteriorating epidemiological situation and the threat of coronavirus. Another reason for refusal was their increased workload (especially in the case of doctors). Therefore, some of the interviews took place over the telephone and several in separate rooms. Interview conversations were recorded on digital media and then transcribed and prepared for analysis. Between 15 and 20 interviews were planned, but not all interviews were informative, so additional interviews were conducted (usually in the same municipality). The selection of interviewees did not involve strict criteria. Calls were most frequently made to municipal institutions, which were asked to be involved in the investigation. In several institutions, interviewees were assisted by representatives of the administration.

Two forms of data collection were used during the interviews: (1) the storyeliciting form of data collection, designed by adapting the data collection strategy of Maynard-Moody and Musheno. The aim was to share experiences during and after the quarantine period while asking participants in the qualitative research to share stories of customer interactions (Maynard-Moody-Musheno 2003). This method of data collection proved its worth during the following research process; (2) a semi-structured form of interviewing.

A cumulative data collection strategy was chosen to explore the roles and involvement of municipalities in the implementation of COVID-19 crisis management policies. The survey of Lithuanian municipal representatives was supplemented by a qualitative study (interviews with municipal heads, heads of administrative units, and council members). 


\section{PRINCIPAL FINDINGS}

\section{The impact of the COVID-19 crisis on the 'burdens' of street- level bureaucracy}

Physicians, social workers, and case managers who work with citizens (and have sufficient discretion) are classified as street-level bureaucrats (SLBs) in street-level bureaucracy studies (Lipsky 2010; Evans 2020). Employees of this public sector professional group usually have a wide level of discretion, and seek to expand and secure it by providing services directly to patients (Checkland 2004; Virtanen et al. 2018). Many front-line workers (especially those working in social care homes, hospital receptions, and with people at social risk) face high levels of uncertainty and pressure arising from a lack of resources and from changing policy requirements. Such practices exist on the service frontlines even during periods of stability.

In the face of the outbreak, street-level bureaucrats not only lacked colleagues to help provide services, but also time. Clearly, this problem was primarily encountered by employees of hospitals and social care institutions where the so-called foci of infection are located. As the interview reveals, the increase in workload was large, and sometimes huge, for a number of reasons. In particular, those working in 'reactors' ${ }^{2}$ were affected by infection control and prevention requirements (appropriate clothing required for working with sick patients, the provision of services according to new procedures/algorithms, etc.) (see Table 2). Second, the workload was increased by staff shortages due to peer isolation or COVID-19 itself. The remaining employees of the institution took over the work of the missing employees. Third, staff were hampered by petty work that "deprived informants of significant minutes or hours from their core business."

Physicians and social service providers spent a lot of time preparing reports (reports and questionnaires were new, and often required submitting to several institutions), delving into the decisions of the heads of operations, documents of municipal administrations, or new methodological material (recommendations, manuals, professional literature, etc.) (see Table 2). Almost all the informants spoke about this with one voice. To reinforce their experience, interviewees repeatedly used the dramatic connotation "insanely" ("insanely increased response to SPPD municipal letters, reporting"; "insanely time-consuming thing [...] We had new orders every day"; “... Yes, that documentation, I will

2 In the jargon of practitioners, specialized COVID-19 treatment units or other units of institutions that were faced with an outbreak of infection were known as "reactors." 


\section{say, was very desperate") ${ }^{3}$. Such rhetoric testifies to the enormous (often almost impossible to manage) workload and other negative effects of constant frustration, tension, and even some signs of alienation from politics.}

\section{Table 2. Interview Data: Huge Workload}

\begin{tabular}{|c|c|}
\hline Topic & Interview Response \\
\hline $\begin{array}{l}\text { Lack of time due to new } \\
\text { infection prevention and } \\
\text { control procedures }\end{array}$ & $\begin{array}{l}\text { "Those dressing processes get stuck, literally. Because you have } \\
\text { to follow the requirements, you have to take the overalls off in the } \\
\text { infected room, put on clean overalls, which takes a lot of time. [...] } \\
\text { Apparently, those safeguards make it cruel, if we were in sweaters, it } \\
\text { would be a whole other thing here. [...] Clearly, fatigue. Let's think } \\
\text { logically, you're used to sitting at the computer all the time, and now } \\
\text { you need to be here all day on your feet. All day - work, go, carry } \\
\text { everyone to the room to eat because they cannot eat in common areas. } \\
\text { You have to climb from the first floor to the second floor seven times } \\
\text { during the feeding process alone. Just take the food away and still } \\
\text { collect it. And that process happens three times a day. Such physical } \\
\text { exertion is definitely not for everyone." (Interview } 25,10-28-2020)\end{array}$ \\
\hline
\end{tabular}

Load due to complex needs and new activities
"We really didn't work for eight hours. We worked, say, for days, and twelve hours and fifteen hours.... Because it was still necessary to take those people out in the evening or there were illnesses among the employees in the team, some of them became infected. [...] But we also had eight hours to rest. Clearly, those eight hours we didn't go out all the time to rest. We made the schedule like this, and changed over - one works and the other goes to rest. [...] The workload was very high, first of all it was much harder for me because my work is more psychological, with documentation, with all the paperwork, and there was physical work here. And until a person is accustomed to that physical work, until a person adapts, the fact is that it is very difficult. It was hard for me personally, but there was no time to think about whether it was hard for you, good for you, or bad for you. You just know you have to go and you have to do it, you just don't think about yourself, and you think about those people [...] to be good for those people because the fact is: some people won't eat, some won't go to the toilet, some can't really do anything. Because there was a real need for all kinds of nursing care, help from the staff because people are really dependent on themselves. It was really very difficult at times, especially until you adapt to that new situation." (Interview 24, 10-27-2020)

"Paperwork and extra [work] contributed greatly. For example, sheet ... [vague observation] must be filled out, and watched as it is filled out. Whether a survey has been done or a survey response has been received ... There are so many extra things that take a lot of time. And how does it complicate the main job - treatment? [...] Treatment takes up a small portion of the work. I can't say the percentage, but really ..." (Interview_4, 10-20-2020)

Source: Prepared by authors

3 Interview_34, 10-14-2020; Interview_15, 10-18-2020; Interview_10, 10-21-2020 


\section{Decreasing discretion}

It can be assumed (although this has scarcely been explored in empirical studies to date) that the discretion of street-level officials changes in the context of a crisis. This is due to several factors. First, in the early stages of a crisis, public policy objectives are not clear or are subject to frequent change. Another important factor, for both physicians and social service providers, is that employees are generally perceived as having wide discretion in decision-making. It is true that a number of studies have revealed that this concept is stereotypical, and the actual discretion of these groups of employees is diminished by detailed operating rules, widely used management standards, information systems, and strict controls (Evans-Harris 2004; Ponnert-Svensson 2016; Brodkin 2007).

Empirical evidence suggests that crisis management policies have had an ambiguous impact on SLBs. On the one hand, the level of discretion involved in working with patients decreased due to the need for documentation of activities, reporting requirements, and the introduction of stricter rules (such as stricter hygiene standards). This was complemented by controls, inspections, and cultural measures introduced by the administration (involving values of mutual support, adjustments to the cooperation and communication style of executives, informal rituals at work - such as signs and remarks about the correct use of self-protection measures, etc.). Staff and physicians felt constrained in their interactions with patients, the application of treatment protocols, etc. Indeed, as some interviewees revealed, some of the staff adapted by overcoming policy constraints. This was revealed in one interview:

[...] Now those rules, recommendations, orders were formed. Not like it was in the beginning. They had become clearer to work with. But when it was said yesterday [interview from the beginning of October 2020] that COVID-19 patients would be here again, I was angry even. I was angry. That's what I thought, that patients from that ward would need to be put here again. [Laughs ironically] A lot of patients are suffering, even [in ways] unrelated to the infection. There are a lot of neglected patients. Really very serious patients, well, well ... (Interview_31, 10-01-2020)

Interview data suggest that uncertainty about the effect of the coronavirus and the COVID-19 disease also shaped the effects of counseling. Specifically, many medical and social service providers had minimal knowledge of epidemiology and responding appropriately. This unclear situation led not only to the aforementioned need for consultations (from the team positioned under the head 
of operations, to epidemiologists accountable to the ministry) but also to stricter protocols (such as detailed explanations of the implementation of procedures in practice). This was particularly important for the organization of work teams, the assignment of tests, the isolation of patients, and so on. Thus, the SLB wanted stricter standards (non-general recommendations with a large number of unknowns) and less discretion in areas related to infection or other issues less familiar to them. This was partly due to highly labile and reactive policies. On the other hand, feelings of uncertainty and the impact of an emotional environment were also important.

\section{THE COPING STRATEGIES OF STREET-LEVEL BUREAUCRATS}

As already examined, some SLBs faced a heavy workload, conflicting requirements (as set out in public policy documents), a lack of resources and other difficulties in working with clients. The situation of some of them led to burnout situations. However, others isolated themselves and moved to work in a safer situation of partial isolation (remote working tools were used for activities, such as video chat platforms, or working with clients by phone). In such different situations and circumstances, SLBs had to overcome the challenges posed by crisis-response policies and other factors and deliver services to the clients. Understandably, SLBs chose slightly different coping strategies. The current research is based on the preconceived theoretical notion that front-line employees engage in similar behaviors (Lipsky 2010) due to their similar working conditions (or what the theorist called "structural" conditions) in their interactions with clients and the effects of public policy. On the other hand, modern empirical research reveals that the concept of coping with a problem depends on its operationalization (Tummers et al. 2015). The aim of this study was to determine the extent to which the COVID-19 pandemic and its consequences affected SLB work as a structural factor. The effects of crisis management policies have also been taken into account.

The first clear strategy is breaking the rules when serving a client. Such a strategy is based on identifying with clients, and taking an active professional role. The interviewees shared their experiences of how they had violated rules during or after quarantine. These strategies were used by social workers and physicians in small towns to provide services to clients at home. Social workers shared their experiences of visiting clients at home in violation of the requirement to provide services remotely: 
We visited some families at home. We were just worried about them. Well, they [the clients' families] were unattended, out of control, and during the quarantine, alcohol abuse increased. I visited some clients. [I] just cared, I felt responsible. After all, we are responsible for them, and you can't do a lot over the phone. [...] Not at the beginning of the quarantine, but after a few weeks. Most importantly, you got it. They were so 'isolated, independent' and then we arrived. And the message spread: 'the social worker came' [laughs] [...] It was a good way. They began to feel again that someone was 'taking care' of them. (Interview_12, 10-09-2020)

This particular interview reveals that social workers exercised their discretion (in their opinion, this did not actually decrease during or after the period of quarantine) and chose a more efficient way of working with clients (client processing). In hospitals and social care homes, this strategy had a slightly different form of expression. First, it was related to visits by patients' or clients' relatives to hospitals and care homes. An analysis of interview data reveals that some hospital physicians did not follow the requirements pertaining to the length of time which patients could spend on visits in the post-quarantine period, and allowed relatives to stay with patients for more than 15 minutes (i.e. these were procedures that were partially followed). The duration of visits to patients in a terminal condition was completely unlimited in practice. The participants of the qualitative research noted that the issue of identity based on humanity was more important than following the rules to the letter.

Another strategy was moving away from the client during the period of quarantine. During the qualitative research, interviewees often mentioned the provision of services in relation to use of the terms 'before quarantine,' 'during quarantine,' and 'post-quarantine.' They also emphasized the change in the way services were provided, emphasizing their experience (many of them worked remotely). After sharing their experiences of the transition to telework, the interviewees immediately moved on to their assessment of aspects of personal acceptability, innovation, or impact on clients, and the overall quality of services. Some clients noted that the 'distance' from clients and use of telephones for consultations (in relation to outpatient treatment, the provision of some social services, or reductions in clients' workload) was acceptable to them because it reduced workload and stress. They emphasized that they continued to work with clients, but only the methods of working and the environment changed in part. According to some participants of the qualitative research, this strategy led to unexpected results, suggesting that some problems could be solved by working with clients over the phone. It should also be emphasized that both teleworking 
and offering outpatient medical services by telephone are possible. At the same time, it was argued that telephone or consultation via Zoom (or other videoconferencing platforms) reduced the accessibility of services to some clients and was of lower quality.

We, here ... [a reference to institution] were uncertain and somewhat confused about the fallen [top-down] instructions from the head of the operation, the ministry, and the municipal administration. And anyway, at the beginning of the pandemic, everything was very, very unclear. But when we moved to remote working during the quarantine, it might have been a new experience. It's like working without clients. Some of us worked from home, some from the office. We rotated [work] among four colleagues. For me, some functions were 'dropped' some social services were missing, but other work had to be done. I worked almost constantly with clients. [...] It was something new, some procedures were simplified and it was more convenient for clients. [...] But this was only during the quarantine. After quarantine, things got back to normal. And then it collapsed - there were about three times as many requests as before the quarantine. And customers came back, well, some at least. .... Everyone is tense, annoyed, dissatisfied with not receiving services in polyclinics. We have become such 'absorbers' here. (Interview_6, 10-14-2020)

This episode of the interview shows that quarantine management policy and changes in service delivery created distance between some SLBs and their clients. Most SLBs understood the short-term nature of the situation and the shortcomings for clients. It should be noted that interviewees who used another approach (a previously examined strategy for overcoming breaches of rules in relation to approaching clients) were very critical of 'telephone counselling' and of reducing the availability of services.

'Service rationing' was another way of coping with problems during and after the quarantine of close officials. 'Service rationalization' is understood as a reduction of service availability or expectations by applying various techniques (queuing, defining service plans for the customer, or limiting contact time). The relevant employees can reduce or postpone individual procedures (e.g., diagnostics, therapy, etc.), limit the time available for consultation, and so on. It is important to note that 'service rationalization' (as a way of overcoming problems) can be multifaceted in nature and application.

An analysis of the qualitative study data revealed that 'service rationing' became an unavoidable means of coping with problems due to the complex 
effects of COVID-19. More specifically, street-level staff were limited not only by resources (some services or procedures were not provided or were severely limited; there were not enough colleagues in the workplace, etc.), time constraints, changes to service delivery (e.g., non-contact) etc., but also extended to protecting the client (or clients, if this was related to a branch or institution). Consequently, the 'rationing of services' could be understood as creating 'distance from the customer' (justifying their potential needs and expectations), but was also justified by the need to ensure security.

One informant, a resident hospital doctor, described her experience of emerging dilemmas and justified the appropriateness of 'service rationing':

And now that goes on as well... Let's say I call a cardiologist or another doctor today and say, 'There are restrictions on certain tests.' You have to explain to him why you are doing this and that. Because in the past, things were really freer. Now you know clearly what you're doing research on, and you change your mind about whether you really need to do it. I think there is a decline in doing excess research [...]. And even consultation. Because now you're doing just what's necessary and thinking hard about whether you really need to drag the patient into another building. And I really felt this a great deal during that quarantine. Because you alone could make decisions. [Take], for example, some bleeding. This used to make people fume, why here, now?! [...] When problems need to be solved, they are solved more quickly [now]. For example, a radiologist used to call and take up some time, listen to what you're doing, this and that, didn't just write down, 'Oh, the residents have come up with something.' Because it used to be that way in the past. You had to defend your decision if you didn't come up with it yourself. And now [the new situation] enables us to take responsibility. I really like that. A few days ago, I had a situation where I found a new clinic for a person, I had to do a whole 'comp' [computed tomography], with the whole spine, it was absurd ... I defended this [process] and said that I had organized it urgently. And there was no particular objection: 'Why are you doing this here?' (Interview_15, 10-18-2020)

In the present case, 'service rationing' is linked to a more precise, narrower allocation of service procedures (mainly diagnostics). The informant mentioned that this practice developed during the first quarantine, and later partially persisted in the post-quarantine period (it was partially abandoned when the number of doctors returning from self-isolation increased, etc.) 
In summary, SLBs used the three most significant coping strategies, driven by the coronavirus pandemic and changes to public policies. The new regimes of service provision only partially reduced the autonomy of their decisions, but changed the way services are delivered. In this case, identities played important roles. Some SLBs identified with customers and violated established rules for the provision of services, while others adapted to new forms of work and the reduced workload.

\section{DISCUSSION}

Empirical research suggests that the COVID-19 pandemic and changes in public policies (social- and personal-health-related) and crisis management solutions affected SLBs differently. The discretion of some of them (those usually found on the frontlines of responding to the virus, institutions with hotspots of infection, hospital receptions, infection hospitals, or their branches, etc.) was significantly reduced. Meanwhile, the decision-making autonomy of most SLBs did not change significantly, nor did workloads increase significantly (on the contrary, they may have decreased slightly during the period of quarantine, while later congestion occurred for only some SLBs).

How has this affected service systems? The findings of qualitative research show that changes to service regimes, persistent uncertainty about policy changes, and a modified service system (often due to the introduction of teleworking, consultation, and reduced access to services for residents) have had the greatest impact. We found that SLB did not substantially conflict with crisis management policymakers regarding significant gaps in interactions with customers. In a crisis environment, the behavior of SLB changed, and they relied on new coping strategies. This is confirmed by other studies of Lithuanian street-level bureaucracy associated with little discretion (Pivoras et al. 2016; Pivoras-Kaselis 2019). Identifying with clients and other cultural factors seems to have played an important role in this, and further analysis thereof would be of interest.

The current research focuses on the coping strategies of SLBs as they pertain to changes in service delivery due to COVID-19. According to research findings, some SLBs did not act according to their typical behavior in a time of crisis management, but developed specific strategies for working with clients. The question remains for further research to what extent SLBs changed or modified strategies throughout the pandemic crisis while working on the frontlines. Also relevant is the question of how institutions (hotspots) and their experiences influence behavioral changes during and after a pandemic. This research agenda 
requires the selection of suitable (key) informants. SLBs who work on the frontlines can reveal the factors that change their roles and their decisions.

\section{CONCLUSIONS}

This article focused on the roles of SLBs in service transformation due to the COVID-19 pandemic. A lack of resources put pressure on medics, as well as social service providers, to find ways to overcome this issue. It was much more difficult for the political-administrative elite and the management of the institutions to solve the problem of the shortage of doctors, nurses, and other specialists in hospitals or social care institutions. This, of course, affected streetlevel bureaucrats as they began to feel the lack of colleagues on the frontlines of the fight against the spread of the disease. Such pressure-related factors and restrictive conditions associated with the provision of services did not occur for all street-level employees. Further from the front line, the situation was much calmer. The workload of some liaison officers decreased, sometimes significantly. The relaxation of COVID-19 policy also ensured the gradual recovery of services. It also changed the workload of street-level bureaucrats, who gradually returned to their original positions, and part of their workload even increased. On the other hand, gradual easing meant balancing between certain constraints (the partial remote provision of services) and the full resumption of service provision. The interview material reveals that workloads increased significantly for some street-level employees. This was first felt by doctors who worked in a non-contact format in both outpatient and inpatient settings. The noticeable increase in social services was felt by daycare centers and other social service providers. Relatives of street-level servants were negatively affected by a feeling of uncertainty in relation to many 'grey' areas in the application of the legislation. Most of the problems arose at the beginning of the first period of quarantine, while later, with the development of so-called algorithms, the description of procedures and operational standards became somewhat clearer. Another area is 'restrictive' public policy decisions or measures (restrictions on access to services, controls on movement, and restrictions in hospitals and social care homes, visits to relatives, etc.) that involved relationships between relatives and their clients. Understandably, clients were often perceived differently because they could limit their needs or behavioral requirements were introduced. It can be concluded that procedures that involved defining different operating conditions than usual resulted in unexpected emotional reactions, loss of control, and some discomfort. 
The constant changes in the decisions of heads of operation reduced the legal ('as described') and de facto ('as affected') discretion of street-level staff. These included activities such as (1) the use of safeguards when working with clients; (2) customer interactions; and (3) teleworking and the provision of services in limited forms. The decision-making autonomy of street-level staff was also reduced due to the assignment of new tasks (the widely used infection control and prevention measures). Clearly defined ('often unchanged or not specified') requirements set forth related to procedures and guidelines for infection control and prevention were relevant to street-level staff working with clients. On the other hand, during quarantine, the former's ability to work with clients in conditions when there was a high risk of infection was formed. SLB were also burdened by excessive monitoring or control of their professional activities, which reduced the autonomy of their decisions.

The forms of problem-solving developed by street-level employees were successful during the quarantine (tightening period), but were too 'alienated' from clients and were only partially appropriate at the end (during the mitigation period). As the qualitative study revealed, some of the established behaviors became strategies for long-term functioning.

\section{REFERENCES}

Alcadipani, R. - S. Cabral - A. Fernandes - G. Lotta (2020) Street-level bureaucrats under COVID-19: Police officers' responses in constrained settings, Administrative Theory \& Praxis, Vol. 42, No. 3., pp. 394-403, DOI: /10.1080/10841806.2020.1771906.

Borrelli, L.M. - A. Lindberg (2018) The creativity of coping: alternative tales of moral dilemmas among migration control officers. International Journal of Migration and Border Studies, Vol. 4, No. 3., pp. 163-178, https://doi. org/10.1504/IJMBS.2018.093876

Brodkin, E. Z. (2007) Bureaucracy redux: Management reformism and the welfare state. Journal of Public Administration Research and Theory, Vol. 17, No.1., pp. 1-17, DOI: doi.org/10.1093/jopart/muj019

Brodkin, E. Z. (2020) Discretion in the welfare state. In: Evans, T. - P. Hupe (eds.): Discretion and the Quest for Controlled Freedom. Cham, Palgrave Macmillan, pp. 63-78, DOI: 10.1007/978-3-030-19566-3

Buffat, A. (2016) When and why discretion is weak or strong: The case of taxing officers in a Public Unemployment Fund. In: Hupe P. - M. Hill (eds.): Understanding Street-level Bureaucracy. Bristol, Policy Press, p. 79. 
Checkland, K. (2004) National Service Frameworks and UK general practitioners: Street-level bureaucrats at work? Sociology of Health \& Illness, Vol. 26, No. 7., pp. 951-975, DOI: 10.1111/j.0141-9889.2004.00424.x

Dubois, V. (2016) The Bureaucrat and the Poor: Encounters in French Welfare Offices. Abingdon (UK), Routledge

Dunlop, C. - E. Ongaro - K. Baker (2020) Researching COVID-19: A research agenda for public policy and administration scholars, Public Policy and Administration, Vol. 35, No. 4., pp. 365-383, DOI: 10.1177/0952076720939631.

Dvorak, J. (2020) Lithuanian COVID-19 lessons for public governance. In: Joyce, P. - F. Maron - P. S. Reddy (eds.): Good Public Governance in a Global Pandemic. Brussels, The International Institute of Administrative Sciences, pp. 329-338.

Dvorak, J. (2021) Response of the Lithuanian municipalities to the First Wave of COVID-19. Baltic Region, Vol. 13, No. 1., pp. 70-88, DOI: 10.5922/20798555-2021-1-4

Dvorak, J. - S. Savickaite (2018) Psichosocialinių paslaugų personalzavimas onkologiniams ligoniams: Lietuvos ir Anglijos lyginamoji analizè. Regional Formation and Development Studies, Vol. 24, No. 1., pp. 133-144, DOI: https://doi.org/10.15181/rfds.v23i1.1689

Ellis, K. (2014) Professional discretion and adult social work: Exploring its nature and scope on the front line of personalisation. The British Journal of Social Work, Vol. 44, No. 8., pp. 2272-2289, DOI: https://doi.org/10.1093/bjsw/bct076

Evans, T. (2020) Professional Discretion in Welfare Services: Beyond StreetLevel Bureaucracy. London, Routledge.

Evans, T. - J. Harris (2004) Street-level bureaucracy, social work and the (exaggerated) death of discretion. The British Journal of Social Work, Vol. 34, No. 6., pp. 871-895, DOI: doi.org/10.1093/bjsw/bch106.

Fontana, I. (2019) The implementation of Italian asylum policy and the recognition of protection in times of crisis: between external and internal constraints. Contemporary Italian Politics, Vol. 11, No. 4., pp. 429-445, DOI: 10.1080/23248823.2019.1680027

Giudici, D. (2020) The list. On discretion and refusal in the Italian asylum system. European Journal of Social Work, Vol. 23, No. 3., pp. 437-448, DOI: 10.1080/13691457.2019.1696754

Hale, T. - A. Petherick - T. Phillips - S. Webster(2020) Variation in government responses to COVID-19. Blavatnik School of Government Working Paper, BSG-WP-2020/031, No. 31., pp. 24-25.

Henderson, A. C. (2012) The critical role of street-level bureaucrats in disaster and crisis response. In: Schwester, R.W. (ed): Handbook of Critical Incident Analysis. New York, Routledge 
Hsiang, S. - D. Allen - S. Annan-Phan et al. (2020) The effect of large-scale anti-contagion policies on the COVID-19 pandemic. Nature, No. 584 (7820), pp. 262-267, DOI: 10.1038/s41586-020-2404-8

Hupe, P. (2007) The frontline supervisor: On the study of leadership at the streetlevel. Workshop 5 'Leadership and the New Public Management'. Leading the Future of the Public Sector: The Third Transatlantic Dialogue, Newark, Delaware, USA, University of Delaware

Hupe, P. (2013) Dimensions of discretion: Specifying the object of street-level bureaucracy research. Der Moderne Staat-Zeitschrift für Public Policy, Recht und Management, Vol. 6, No. 2., pp. 425-440.

Hupe, P. - A. Buffat (2014) A public service gap: Capturing contexts in a comparative approach of street-level bureaucracy. Public Management Review, Vol. 16, No. 4., pp. 548-569, DOI: 10.1080/14719037.2013.854401

Lipsky, M. (1980) Street-Level Bureaucracy: Dilemmas of the Individual in Public Services, New York, Sage

Lipsky, M. (2010) Street-Level Bureaucracy: Dilemmas of the individual in public service. New York, Russell Sage Foundation, pp. 14-15.

Maynard-Moody, S. W. - M. Musheno (2003) Cops, Teachers, Counselors: Stories from the Front Lines of Public Service. Michigan, University of Michigan Press

Pivoras, S. - R. Civinskas - E. Buckienè - M. Kaselis (2016) The Role of Administrative Identities in Assuring Accountability of Street-Level Bureaucracies to Citizens: Case of two Lithuanian Agencies. Conference paper: EGPA Annual Conference, August 2016, Utrecht, NL. https://www.researchgate. net/publication/316621260_The_Role_of_Administrative_Identities_in_Assuring_Accountability_of_Street-Level_Bureaucracies_to_Citizens_Case_ of_two_Lithuanian_Agencies

Pivoras, S. - N. Gončiarova (2017) Valstybès tarnautojų profesinė diskrecija aptarnaujant valstybinès įdarbinimo tarpininkavimo agentūros klientus: Lietuvos darbo biržos atvejis. [Professional Discretion of Civil Servants in Serving the Customers of Public Employment Intermediation Agency: The Case of Lithuanian Labour Exchange.] Viešoji Politika ir Administravimas, Vol. 16, No. 3., pp. 424-437, DOI: https://doi.org/10.5755/ j01.ppaa.16.3.19340

Pivoras, S. - M. Kaselis (2019) The impact of client status on street-level bureaucrats' identity and informal accountability, Public Integrity, Vol. 21, No. 2., pp. 182-194, DOI: doi.org/10.1080/10999922.2018.1433424

Ponnert, L. - K. Svensson (2016) Standardisation - the end of professional discretion? European Journal of Social Work, Vol. 19, No. 3-4., pp. 586-599 DOI: $10.1080 / 13691457.2015 .1074551$ 
Raaphorst, N. (2018) How to prove, how to interpret and what to do? Uncertainty experiences of street-level tax officials. Public Management Review, Vol. 20, No. 4., pp. 485-502, DOI: 10.1080/14719037.2017.1299199

Raaphorst, N. - S. Groeneveld (2019) Discrimination and representation in street-level bureaucracies. In: Hupe, P. (ed.) Research Handbook on StreetLevel Bureaucracy. Chelteham, UK, Edward Elgar Publishing, pp. 116-127 Raś, K. (2020) The Baltic States and COVID-19, PISM Bulletin, No. 96, pp. 1-2. Scourfield, P. (2015) Even further beyond street-level bureaucracy: The dispersal of discretion exercised in decisions made in older people's care home reviews. The British Journal of Social Work, Vol. 45, No. 3., pp. 914-931, DOI: https:// doi.org/10.1093/bjsw/bct175

Sicgling, F. (2020) 'Mutatio Sub Pressura': An exploration of the youth policy response to the Syrian refugee crisis in Germany. Journal of Social Policy, July, 2020, pp. 1-19, DOI: https://doi.org/10.1017/S0047279420000392

Small, M. L. (2006) Neighborhood institutions as resource brokers: Childcare centers, interorganizational ties, and resource access among the poor. Social Problems, Vol. 53, No. 2., pp. 274-292, DOI: https://doi.org/10.1525/ sp.2006.53.2.274

Sowa, J. E. - S. Selden (2003) Administrative discretion and active representation: An expansion of the theory of representative bureaucracy. Public Administration Review, Vol. 63, No. 6., pp.700-710, DOI: https://doi. org/10.1111/1540-6210.00333

Spitzmueller, M. C. (2014) The Making of Community Mental Health Policy in Everyday Street-Level Practice: An Organizational Ethnography. Chicago, The University of Chicago. ProQuest Dissertations Publishing, UMI: 3615678.

Trappenburg, M. - T. Kampen - E. Tonkens (2020) Social workers in a modernising welfare state: professionals or street-level bureaucrats? The British Journal of Social Work, Vol. 50, No. 6., pp. 1669-1687, https://doi. org/10.1093/bjsw/bcz120

Tummers, L.G. - V.J. Bekkers - E. Vink - M. Musheno (2015) Coping during public service delivery: A conceptualization and systematic review of the literature. Journal of Public Administration Research and Theory, Vol. 25, No. 4., pp. 1099-1126, DOI: 10.1093/jopart/muu056

Tummers, L.G. - V.J. Bekkers (2014) Policy implementation, street-level bureaucracy, and the importance of discretion. Public Management Review, Vol. 16, No. 4., pp. 527-547, DOI: 10.1080/14719037.2013.841978

Turrini, A. - D. Cristofoli - G. Valotti (2020) Sense or sensibility? Different approaches to cope with the COVID-19 pandemic. The American Review of Public Administration, Vol. 50, No. 6-7., pp. 746-752, DOI: $10.1177 / 0275074020942427$ 
Van Bavel, J. J. - K. Baicker - P. S. Boggio et al. (2020) Using social and behavioural science to support COVID-19 pandemic response. Nature Human Behaviour, No. 4., pp. 460-471, DOI: 10.1038/s41562-020-0884-Z

Van Engen, N. - B. Steijn - L. Tummers (2019) Do consistent government policies lead to greater meaningfulness and legitimacy on the front line? Public Administration, Vol. 97, No. 1., pp. 97-115, DOI: https://doi.org/10.1111/ padm. 12570

Virtanen, P. - I. Laitinen - J. Stenvall (2018) Street-level bureaucrats as strategy shapers in social and health service delivery: Empirical evidence from six countries, International Social Work, Vol. 61, No. 5., pp. 724-737, DOI: doi.org/10.1177/0020872816660602

Watkins-Hayes, C. (2009) The New Welfare Bureaucrats: Entanglements of Race, Class, and Policy Reform. Chicago, University of Chicago Press, p. 187.

Weible, C. M. - D. Nohrstedt - P. Cairney - D. P. Carter - D. A. Crow A. P. Durnová - T. Heikkila - K. Ingold - A. McConnell - D. Stone (2020) COVID-19 and the policy sciences: initial reactions and perspectives. Policy Sciences, No. 53., pp. 225-241, DOI: 10.1007/s11077-020-09381-4 